\title{
PENGARUH PENGGUNAAN MEDIA FILM DOKUMENTER TERHADAP HASIL BELAJAR PESERTA DIDIK KELAS V MATA PELAJARAN IPS
}

\section{THE INFLUENCE OF DOCUMENTARY FILM MEDIA USAGE TOWARDS STUDENTS' LEARNING RESULTS OF SOCIAL SCIENCE IN CLASS V}

\author{
Linda Robaniatun', Agus Gunawan ${ }^{2}$, Arrofa Acesta ${ }^{3}$ \\ ${ }^{1}$ SD Negeri Pajambon \\ ${ }^{2,3}$ PGSD FKIP Universitas Kuningan \\ ${ }^{1}$ lindarobaniatun@gmail.com, ${ }^{2}$ agus.gunawan@uniku.ac.id, ${ }^{3}$ arrofa.acesta@uniku.ac.id
}

Pengutipan: Robaniatun, L., Gunawan, A., \& Acesta, A. (2019). Pengaruh penggunaan media film dokumenter terhadap hasil belajar peserta didik kelas $\mathrm{V}$ mata pelajaran IPS. Pedagogi: Jurnal Penelitian Pendidikan, 6 (2), hlm $15-23$.

Diajukan: 07-12-2019 Diterima: 16-12-2019_Diterbitkan: 17-12-2019

\begin{abstract}
ABSTRAK
Masalah dalam penelitian ini adalah hasil belajar siswa pada pelajaran IPS yang masih rendah. Karena masih kurangnya penggunaan media dalam proses pembelajaran sehingga siswa merasa jenuh dan kurang berminat dalam mengikuti pembelajaran, yang pada akhirnya akan mempengaruhi hasil belajar siswa. Tujuan penelitian ini adalah untuk mengetahui apakah terdapat perbedaan hasil belajar (posttest) siswa antara kelas yang menggunakan media pembelajaran film dokumenter dengan kelas yang menggunakan media pembelajaran komik dan perbedaan peningkatan hasil belajar (gain) siswa pada kelas yang menggunakan media pembelajaran komik dengan kelas yang menggunakan media pembelajaran film dokumenter pada pelajaran IPS Kelas V SD Negeri Pajambon. Metode penelitian yang digunakan adalah metode eksperimen dengan desain non-equivalent group pretestt-posttestt design, yang dilakukan di SD Negeri Pajambon. Dengan sampel yang terdiri dari kelas VA sebagai kelas kontrol dengan jumlah siswa 20 orang dan VB sebagai kelas eksperimen dengan jumlah siswa 23 orang. Hasil penelitian dengan pengujian secara statistik menunjukan terdapat perbedaan hasil belajar (posttest) siswa, maka penggunaan media film dokumenter lebih efektif dibandingkan dengan pembelajaran dengan menggunakan media komik. Sedangkan hasil perhitungan uji-t (gain) menunjukkan terdapat perbedaan peningkatan hasil belajar siswa, maka terdapat peningkatan (gain) hasil belajar siswa antara pembelajaran dengan menggunakan media komik dan pembelajaran dengan menggunakan media film dokumenter. Hal ini menunjukan bahwa media pembelajaran film dokumenter dapat meningkatkan hasil belajar siswa.
\end{abstract}

Kata Kunci: hasil belajar; IPS; media film dokumenter

\section{ABSTRACT}

The problem of this research is the students' learning result towards IPS subject which is still low. It is because of the lack of media used in the learning process so that the students feel 
bored and less interested in following the lesson, which will ultimately affect students' learning result. The purpose of this study was to know whether there are differences in learning result (posttest) of students between classes that use documentary film media with classes that use comics media and the differences of students' learning result in class that use comics media with class that use instructional media documentary film on social science subjects Class $V$ Elementary School Pajambon. The research method used was the experimental method with the design of non-equivalent group pretest-posttest design, conducted in Elementary School Pajambon. The samples consisted VA class as an control class with a total of 20 students and VB as a experimental class with a student population of 23 people. The result of the research with statistical test showed that there are differences of learning result (posttest) of students' the use of documentary film media is more effective than learning with comics media. While the result of $t$ test (gain) showed that there are differences in the increase of students, then there is an increase (gain) of students' learning result between learning by using comics media and learning by using documentary film media. This shows that documentary film learning media can improve students' learning result.

Keywords: learning result; social science; documentary film media 


\section{PENDAHULUAN}

Belajar merupakan sebuah proses perubahan di dalam kepribadian manusia sebagai hasil dari pengalaman atau interaksi antara individu dengan lingkungan. Perubahan tersebut ditampakkan dalam bentuk peningkatan kualitas dan kuantitas tingkah laku seperti peningkatan kecakapan, pengetahuan, sikap, kebiasaan, pemahaman, keterampilan, daya pikir, dan kemampuan-kemampuan lain. Perubahan inilah yang menjadi tolak ukur keberhasilan proses belajar yang dialami oleh peserta didik. Selain itu, gaya belajar peserta didik merupakan kombinasi dari bagaimana ia menyerap serta mengolah informasi (Karwati, 2015: 188).

Berdasarkan hasil observasi di lapangan, dengan melihat hasil ulangan harian terutama pada muatan IPS tema 6 subtema 3 pembelajaran 4 yang menghasilkan ketuntasan hasil belajar pada kelas Va yang berjumlah 20 orang yaitu 6 orang dengan nilai lebih dari 70 dan yang tidak mencapai KKM sebanyak 14 orang. Pada kelas Vb dengan jumlah peserta didik 23 orang, terdapat 9 orang yang berhasil mendapatkan nilai lebih dari 70 dan 14 orang yang mendapatkan nilai di bawah KKM. Jika dikumulatifkan dari keseluruhan peserta didik yang berjumlah 43 orang, maka peserta didik yang telah memenuhi KKM sebanyak 15 orang.

Untuk mengetahui permasalahan atas hasil belajar peserta didik yang rata-rata di bawah KKM tersebut, maka dilakukan penyebaran angket pada peserta didik. Hasil dari penyebaran angket menyatakan bahwa pada tiga pernyataan yang diajukan mendapatkan hasil di bawah 50\% dari jumlah 43 siswa. Terdapat tiga penyataan dan empat alternative jawaban yaitu Selalu (4), Sering (3), Kadang-kadang (2), dan Tidak pernah (1), menunjukkan bahwa 47\% menyatakan muatan IPS menyenangkan, 44\% penyampaian materi IPS mudah dipahami, dan $42 \%$ menyatakan bahwa dalam penyajian materi IPS menggunakan media pembelajaran atau alat peraga. Sehingga dapat disimpulkan bahwa sebagian besar muatan IPS kurang diminati, kurang menyenangkan serta sulit dipahami.

Adanya observasi pra-penelitian dengan penyebaran angket dan observasi mengenai hasil ulangan tersebut dapat disimpulkan bahwa terdapat beberapa kesulitan dalam hasil belajar peserta didik khususnya muatan IPS, diantaranya: terdapat peserta didik yang kurang mengerti mengenai muatan IPS; beberapa peserta didik kesulitan menjelaskan materi atau membuat kesimpulan dengan Bahasa sendiri; bahkan ada peserta didik yang tidak bersemangat saat mengikuti pembelajaran. Hal tersebut menyebabkan hasil belajar peserta didik pada proses pembelajaran IPS sangat rendah.

Permasalahan di atas dapat diatasi dengan beberapa cara salah satunya dengan menggunakan media pembelajaran. Media merupakan suatu alat atau sarana atau perangkat yang berfungsi sebagai perantara atau saluran atau jembatan dalam kegiatan komunikasi (penyampaian dan penerimaan pesan) antara komunikator atau penyampai pesan dan komunikan atau penerima pesan (Miftah, 2013 : 97). Media pembelajaran memiliki pengaruh penting dalam keberlangsungan pembelajaran yang dilakukan. Kelebihan dari penggunaan media pembelajaran adalah membuat pembelajaran menarik dan bervariasi, merangsang imajinasi siswa, mengkongkritkan yang abstrak sehingga pembelajaran menjadi efektif dan aktif (Husmiati, 2010: 62-67). Terlebih jika media pembelajaran yang digunakan berupa media audio visual maka dapat meningkatkan kualitas belajar peserta didik. Media audio visual seperti video atau film efektif digunakan ketika materi yang disampaikan tidak dapat dipraktikan di dalam kelas atau membutuhkan waktu yang lama. Film documenter menurut Grierson (Narayana, 2017) menyatakan bahwa documenter merupakan suatu bentuk informasi, propaganda, edukasi, dan cara kreatif untuk mempresentasikan realita.

Berdasarkan latar belakang tersebut, maka peneliti merasa tertarik untuk mengkaji dalam bentuk penelitian yang berjudul "PENGARUH PENGGUNAAN MEDIA FILM DOKUMENTER TERHADAP HASIL BELAJAR PESERTA DIDIK KELAS V 
PELAJARAN IPS (Studi Quasi Eksperimen pada Peserta didik Kelas V Pelajaran IPS Tema 7 Subtema 2 SD Negeri Pajambon Kecamatan Kramatmulya Kabupaten Kuningan)”

\section{METODE PENELITIAN}

Penelitian ini termasuk ke dalam jenis penelitian kuantitatif dengan metode eksperimen (Quasi Experimental Design). Menurut Sugiyono (2017: 114) bentuk desain eksperimen ini merupakan pengembangan dari true experimental design, yang sulit dilaksanakan. Desain ini mempunyai kelompok kontrol, tetapi tidak dapat berfungsi sepenuhnya untuk mengontrol variabel-variabel luar yang mempengaruhi pelaksanaan eksperimen. Walaupun demikian, desain ini lebih baik dari pre-experimental design. Quasi Experimental Design, digunakan karena pada kenyataannya sulit mendapatkan kelompok kontrol yang digunakan untuk penelitian.

Desain Nonequivalent Control Group Design hampir sama dengan pretest-posttest control group design, hanya pada desain Nonequivalent Control Group Design ini kelompok eksperimen dan kelompok kontrol tidak dipilih secara random.

\begin{tabular}{|cccc|}
\hline $\mathrm{E}$ & $\mathbf{O}_{\mathbf{1}}$ & $\mathbf{X}_{\mathbf{1}}$ & $\mathbf{O}_{\mathbf{2}}$ \\
& $\cdots \cdots \cdots \cdots \cdots \cdots \cdots \cdots \cdots .$. & \\
$\mathrm{K}$ & $\mathbf{O}_{\mathbf{3}}$ & $\mathbf{X}_{2}$ & $\mathbf{O}_{\mathbf{4}}$ \\
\hline
\end{tabular}

Gambar 1. Desain Penelitian Nonequivalent Control Group Design

Keterangan:

$\mathrm{E} \quad=$ Kelas eksperimen

$\mathrm{K}=$ Kelas kontrol

$\mathrm{O}_{1} \quad=$ Test awal (pretest)

$\mathrm{O}_{2} \quad=$ Tes akhir (posttest) dengan perlakuan media film dokumenter

$\mathrm{O}_{3} \quad=$ Tes awal (pretest)

$\mathrm{O}_{4}=$ Tes akhir (posttest) dengan perlakuan media komik

$\mathrm{X}_{1}=$ Perlakuan menggunakan media film dokumenter

$\mathrm{X}_{2} \quad=$ Perlakuan menggunakan media media komik

(Arikunto, 2014: 125)

Penelitian dilaksanakan pada bulan Mei 2018 di SD Negeri Pajambon yang berlokasi di Dusun Wage, RT 8 RW 4 Desa Pajambon Kec. Kramatmulya Kab. Kuningan. Setelah melakukan observasi lapangan penelitian akan dilaksanakan pada kelas V SD Negeri Pajambon. Kelas V tersebut terdiri dari 2 rombel dengan jumlah siswa kelas VA berjumlah 20 orang dan kelas VB berjumlah 23 orang.

Penelitian ini dilakukan melalui beberapa prosedur tahapan penelitian yang telah direncanakan sebelumnya. Tahapan penelitian tersebut meliputi tiga tahapan utama, yaitu tahapan persiapan, tahapan pelaksanaan, dan tahapan akhir. Untuk lebih jelasnya peneliti sajikan prosedur penelitian dalam tahapan sebagai berikut:

Tahapan persiapan meliputi: (a) pembuatan instrument penelitian yaitu akan digunakan tes objektif berupa soal pilihan ganda; (b) soal objektif akan dikonfirmasikan terlebih dahulu dengan dosen pembimbing; (c) melakukan uji coba soal tes pilihan ganda, bertujuan untuk mencari validitas, reliabilitas,tingkat kesukaran, dan daya pembeda, soal tes objektif tersebut; (d) menganalisis validitas, reliabilitas, tingkat kesukaran, dan daya pembeda instrument; (e) menemukan sampel yang akan dijadikan subjek dalam penelitian; (f) penggandaan instrumen sesuai dengan jumlah sampel yang dibutuhkan. Tahapan pelaksanaan meliputi: (a) memilih subjek penelitian yaitu peserta didik kelas V SD Negeri Pajambon; (b) menentukan kelompok penelitian; (c) melakukan tes awal (pretest); (d) proses belajar dan pembelajaran; (e) 
melakukan tes akhir (posttest). Sedangkan tahapan akhir meliputi: (a) pengolahan data hasil tes; (b) pembuatan laporan; (c) kesimpulan.

Teknik analisis data dalam penelitian kuantitatif menggunakan statistik. Uji normalitas yang dilakukan menggunakan uji normalitas Chi Kuadrat. Menurut Riduwan (2018: 141-144) prosedur penerapannya sebagai berikut: (a) mencari skor terbesar dan terkecil; (b) mencari nilai Rentangan ( $\mathrm{R}$ ); (c) $\mathrm{R}=$ skor terbesar - skor terkecil; (d) mencari Banyaknya Kelas (BK); (e) $\mathrm{BK}=1+3,3 \log \mathrm{n}$ (Rumus Sturges); (f) mencari nilai panjang kelas (i); (g) membuat tabulasi dengan tabel penolong; (h) mencari rata-rata (mean); (i) mencari simpangan baku (standart deviasi) $s=\sqrt{\frac{n \cdot \Sigma f X_{1}^{2}-\left(\Sigma f X_{1}\right)^{2}}{n \cdot(n-1)}} ;(\mathrm{j})$ membuat daftar frekuensi; (k) mencari chi-kuadrat hitung $\left(X_{\text {hitung }}^{2}\right)$; (1) membandingkan $X_{\text {hitung }}^{2}$ dengan $X_{\text {tabel }}^{2}$

Uji homogenitas yaitu untuk mengukur homogenitas varians dari dua kelompok data, digunakan rumus uji F. Menurut Riduwan (2018: 140-141) Prosedur pengujian homogenitas data sebagai berikut: (a) mencari nilai varians terbesar dan varians terkecil; (b) membandingkan nilai $\mathrm{F}_{\text {hitung }}$ dengan $\mathrm{F}_{\text {tabel. }}$

Uji statistik hipotesis diartikan sebagai pernyataan mengenai keadaan populasi (parameter) yang akan diuji kebenarannya berdasarkan data yang diperoleh dari sampel penelitian (statistik) (Sugiyono, 2017: 224 - 231). Jadi maksudnya adalah taksiran keadaan populasi melalui data sampel. Oleh karena itu dalam statistic yang diuji adalah hipotesis nol. Hipotesis nol adalah pernyataan tidak adanya perbedaan antara parameter dengan statistic. Lawan dari hipotesis nol adalah hipotesis alternatif, yang menyatakan ada perbedaan antara parameter dengan statistik. Hipotesis nol diberi notasi Ho, dan hipotesis alternative diberi notasi Ha.

Uji hipotesis yang dilakukan yaitu dengan menggunakan rumus uji $t$ sebagai berikut.

$$
\mathrm{t}=\frac{\bar{X}_{1}-\bar{X}_{2}}{\sqrt{\frac{s_{1}^{2}}{n_{1}}+\frac{s_{1}^{2}}{n_{1}}-2 r\left(\frac{s_{1}}{\sqrt{n_{1}}}\right)\left(\frac{s_{2}}{\sqrt{n_{2}}}\right)}}
$$

(Sugiyono, 2017: 274)

Apabila $t_{\text {hitung }}$ lebih kecil atau sama dengan $t_{\text {tabel }}$, maka Ho diterima. Sedangkan apabila $\mathrm{t}_{\text {hitung }}$ lebih besar atau sama dengan $\mathrm{t}_{\text {tabel }}$, maka Ho diterima

\section{HASIL PENELITIAN DAN PEMBAHASAN}

Penelitian ini bertujuan untuk melihat dan mendeskripsikan mengenai pengaruh penggunaan media film dokumenter terhadap hasil belajar peserta didik (Studi quasi eksperimen pada peserta didik kelas V pelajaran IPS tema 7 subtema 2 SD Negeri Pajambon kecamatan Kramatmulya kabupaten Kuningan). Penelitian ini berjenis penelitian kuantitatif metode eksperimen (Quasi Eksperimen Design) dengan menggunakan pretest dan posttest dengan tipe "nonequivalent control group design". Untuk melihat pengaruh penggunaan media film dokumenter peneliti menggunakan kelas eksperimen dan kelas kontrol. Kedua kelas tersebut menggunakan perlakuan yang berbeda.

Peneliti melakukan pra-penelitian dengan memberi angket kepada peserta didik kelas V dengan tujuan untuk mengetahui pembelajaran yang telah dilakukan terutama dalam penggunaan media pembelajaran pada pelajaran IPS. Hasil dari penyebaran angket menunjukkan peserta didik kurang menyukai pelajaran IPS, salah satu faktor penyebabnya adalah guru belum menggunakan media berbasis teknologi. Sehingga peneliti media pembelajaran film dokumenter sebagai solusinya. Selanjutnya peneliti mengidentifikasi materi yang akan ditingkatkan, materi tersebut diambil dari tema 7 Peritiwa dalam kehidupan, subtema 2 peristiwa kebangsaan seputar proklamasi kemerdekaan, pembelajaran 1. Kompetensi dasar 3.4 mengidentifikasi faktor-faktor penting penyebab penjajahan bangsa 
Indonesia dan upaya bangsa Indonesia dalam mempertahankan kedaulatannya. Dan indikator pencapaian kompetensi yaitu 3.4.1 mengetahui proses dalam peristiwa seputar pembacaan teks proklamasi kemerdekaan Indonesia; 3.4.2 menjelaskan peristiwa seputar pembacaan teks proklamasi kemerdekaan Indonesia; serta 3.4.3 menyebutkan tokoh-tokoh serta perannya yang terlibat dalam peristiwa seputar proklamasi kemerdekaan Indonesia.

Instrumen yang digunakan berupa soal pilihan ganda dengan jumlah pre-test 20 soal dan post-test 20 soal. Sebelum digunakan pada kelas $\mathrm{V}$, peneliti melakukan uji coba instrumen dengan menggunakan beberapa analisis yaitu uji validitas, uji reliabilitas, uji taraf kesukaran soal, dan uji daya pembeda soal, dengan hasil 40 soal valid, reliabitias 1,01 dengan kategori sangat tinggi, tingkat kesukaran terdapat tiga yaitu kategori mudah $27 \%$, sedang $55 \%$, dan sukar $18 \%$, serta uji daya pembeda memperoleh hasil 40 soal baik sekali. Sehingga soal tersebut dapat digunakan.

Penelitian dilakukan selama tiga pertemuan. Pertemuan pertama pada kelas VA peneliti melakukan pembelajaran tanpa menggunakan media pembelajaran dan pada akhir pembelajaran peneliti memberikan soal pre-test untuk mengetahui kemampuan awal kognitif peserta didik. Dari hasil pre-test untuk kelas VA memperoleh nilai rata-rata 56,25 sedangkan kelas VB nilai rata-ratanya sebesar 54,57 sehingga peneliti memilih kelas VB sebagai kelas eksperimen yang akan diberi perlakuan menggunakan media pembelajaran film dokumenter dan kelas VA sebagai kelas kontrol meskipun keduanya tidak terdapat perbedaan yang signifikan namun kelas VA lebih unggul. Selanjutnya pada pertemuan kedua di kelas eksperimen dilakukan pembelajaran dengan menggunakan media film dokumenter, untuk mengetahui pemahaman peserta didik peneliti melakukan tanya jawab. Sedangkan pada kelas kontrol pembelajarannya menggunakan media komik.

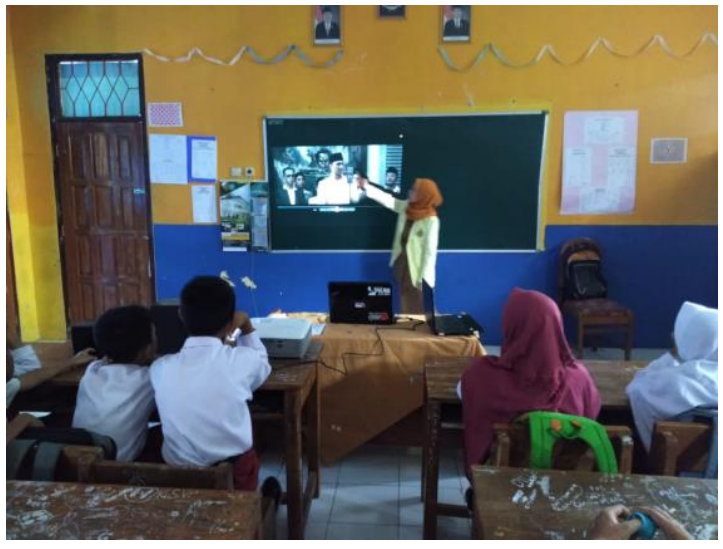

Gambar 2. Penayangan Film Dokumenter

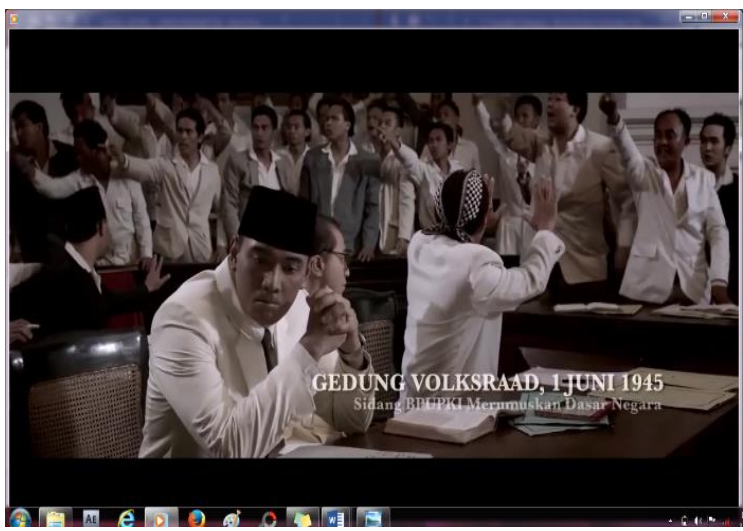

Gambar 3. Film Dokumenter

Pada pertemuan ketiga, pembelajaran pada kelas eksperimen kembali menggunakan media film dokumenter guna memperkuat daya ingat peserta didik, selesai pembelajaran peneliti memberikan soal post-test atau tes akhir. Begitupun dengan kelas kontrol setelah pembelajaran dengan media komik peneliti memberikan post-test atau tes akhir. Dengan hasil rata-rata kelas eksperimen 85,87 sedangkan kelas kontrol 78,50 artinya terdapat perbedaan nilai rata-rata kelas antara kelas eksperimen dan kelas kontrol sebesar 7,37.

Berdasarkan proses pembelajaran di atas, peneliti melakukan analisis data menggunakan uji prasyarat dan uji hipotesis serta uji N-Gain. Uji prasyarat yang digunakan adalah uji normalitas dan uji homogenitas. Hasil pada uji normalitas dengan menggunakan rumus Riduwan yaitu $X_{\text {hitung }}^{2}<X_{\text {tabel }}$ dengan $\alpha=5 \%$ dan derajat kebebasan 2 sehingga $X_{\text {tabel }}=$ 5,991 sedangkan $\mathrm{X}^{2}$ hitung pre-test kelas kontrol 1,13; post-test kelas kontrol 2,19; pre-test kelas eksperimen 4,16; dan post-test kelas eksperimen 4,91. Dapat disimpulkan bahwa 
keempat hasil hitung $X_{\text {hitung }}^{2}<X_{\text {tabel }}$ sehingga berdistribusi normal. Sedangkan uji homogenitas dengan ketentuan $\mathrm{F}_{\text {hitung }}<\mathrm{F}_{\text {tabel }}$ memperoleh hasil $\mathrm{F}_{\text {hitung }}$ pada pre-test kelas kontrol dan eksperimen sebesar 1,14 dan pada post-test kelas kontrol dan kelas eksperimen sebesar 1,28 dengan nilai $\mathrm{F}_{\text {tabel }}=2,08$. Maka, hal tersebut dinyatakan homogen.
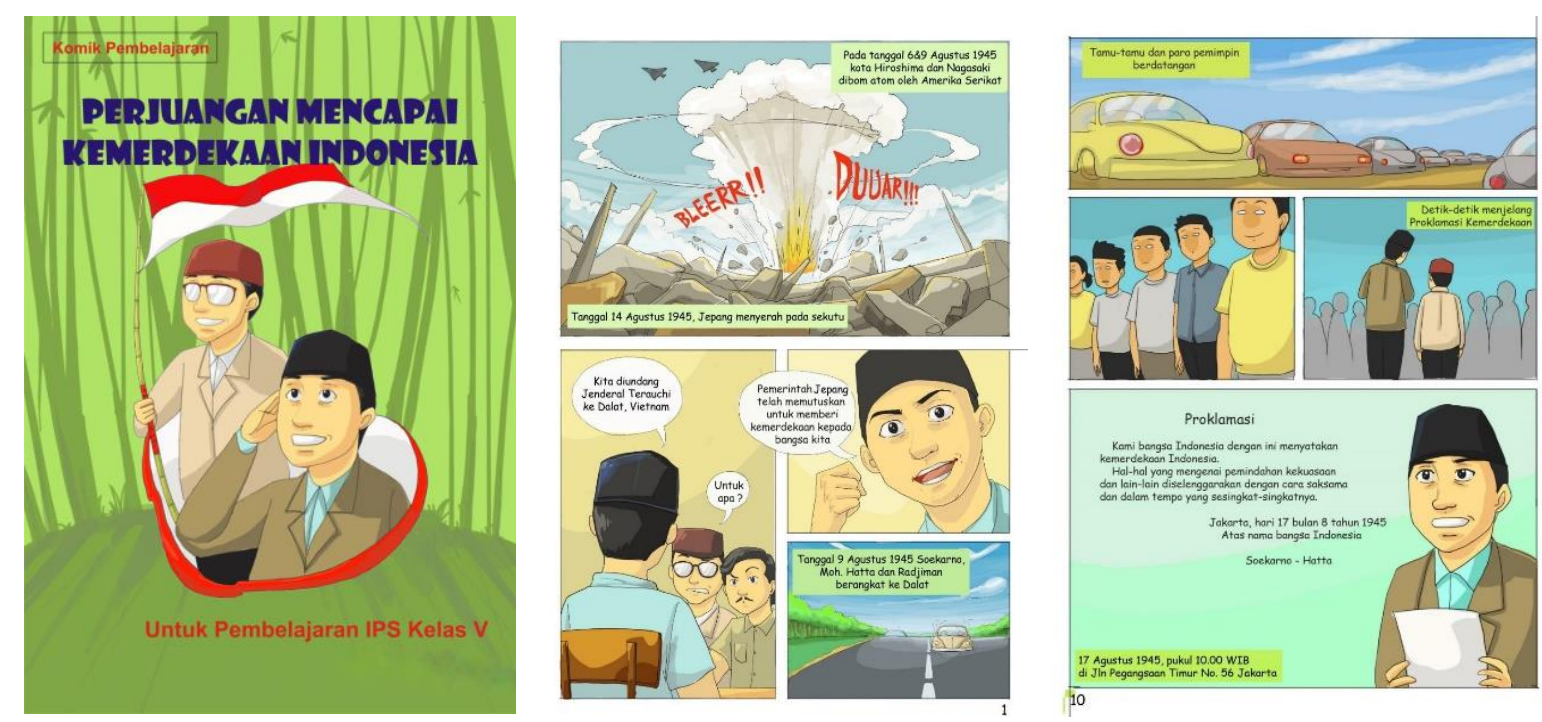

Gambar 4. Komik

Hasil pengujian dengan menggunakan uji perbedaan dua rata-rata (uji t) dari hasil posttest diperoleh $t_{\text {hitung }}>t_{\text {tabel }}$. Pada taraf signifikan $5 \%(\alpha=0,05)$ dengan derajat kebebasan $\mathrm{db}=41$ diperoleh $t_{\text {hitung }} 2,06>t_{\text {tabel }}$ 2,019. Ini berarti terdapat perbedaan yang signifikan antara hasil post-test kelas eksperimen dan kelas kontrol. Hal ini sejalan dengan penelitian Maiyena dan Yani Pinta yang mendapatkan hasil uji t pada penelitiannya sebesar $t_{\text {hitung }}=$ 3,39 dan $t_{\text {tabel }}=1,667$. Dengan kriteria pengujian terima Ho jika $\mathrm{t}<t_{1-\alpha}$ dan tolak jika mempunyai harga lain, pada taraf nyata $\alpha=0,05$ dengan derajat kebebasan $=n_{1}+n_{2}-2$ artinya, dimana $t_{\text {hitung }}>t_{\text {tabel }}$ sehingga hipotesis nol ditolak dan hipotesis kerja $\left(\mathrm{H}_{1}\right)$ diterima.

Selain itu, berdasarkan hasil analisis data yang diperoleh nilai $\mathrm{N}$-gain kelas eksperimen sebesar 0,74 dan kelas kontrol sebesar 0,53. Nilai tersebut selanjutnya diinterprestasikan ke dalam kriteria N-gain. Setelah diinterprestasikan diperoleh nilai N-gain kelas eksperimen dengan menggunakan media film dokumenter tergolong tinggi, sedangkan untuk kelas kontrol dengan menggunakan media komik tergolong sedang.

Setelah dilakukan uji perbedaan rata-rata (uji t) gain diperoleh $t_{\text {hitung }}$ sebesar 3,5 dan $t_{\text {tabel }}$ 2,019 maka $t_{\text {hitung }}>t_{\text {tabel }}$. Dengan demikian hipotesis yang peneliti ajukan terbukti kebenarannya bahwa penggunaan media film dokumenter dalam pembelajaran mampu meningkatkan hasil belajar peserta didik lebih meningkat. Hal ini sejalan dengan penelitian Suarmika, Pudjawan, \& Sudarma bahwa media pembelajaran film pendek efektif meningkatkan hasil belajar dengan $t_{\text {hitung }}=13,08>t_{\text {tabel }}=2,042$ dengan taraf signifikan $5 \%$.

Dengan rutin menggunakan media film dokumenter dalam pembelajaran maka hasil belajar IPS akan semakin meningkat. Hal ini disebabkan karena media film dokumenter dapat membuat pembelajaran yang abstrak menjadi konkret, dapat mempermudah dan memperdetail dalam menjelaskan peristiwa, pembelajaran menjadi menyenangkan serta membuat peserta didik kritis memahami peristiwa sejarah. 


\section{SIMPULAN DAN SARAN}

Berdasarkan hasil analisis data dan pengujian hipotesis yang telah diperoleh dari hasil pretest dan posttest pada pembelajaran IPS di kelas V SD Negeri Pajambon, Kramatmulya Kabupaten Kuningan, maka dapat diambil kesimpulan bahwa: (a) Terdapat perbedaan hasil belajar peserta didik di kelas kontrol dan kelas eksperimen setelah diberi perlakuan (posttest). Artinya hasil belajar peserta didik pada kelas yang menggunakan media film dokumenter lebih efektif; dan (b) Terdapat perbedaan peningkatan (gain) hasil belajar peserta didik pada kelas yang menggunakan media film dokumenter (kelas eksperimen). Artinya penggunaan media film dokumenter dalam pembelajaran mampu meningkatkan hasil belajar siswa lebih unggul. Dengan hasil tersebut maka peneliti menarik kesimpulan dari penelitian ini bahwa media film dokumenter dalam pembelajaran berpengaruh positif terhadap hasil belajar siswa. 


\section{DAFTAR PUSTAKA}

Arikunto, Suharsimi. (2014). Prosedur penelitian: suatu pendekatan praktik. Jakarta: Rineka Cipta.

Husmiati, R. 2010. Kelebihan dan kelemahan media film sebagai media pembelajaran sejarah, Jurnal Sejarah Lontar, Volume 7 Nomor 2.

Karwati, Euis. 2015. Manajemen kelas (classroom management) guru profesional yang inspiratif, kreatif, menyenangkan, dan berprestasi. Bandung: Alfabeta.

Miftah, M. 2013. Fungsi dan peran media pembelajaran sebagai upaya peningkatan belajar siswa, Jurnal KWANGSAN, Volume 1 Nomor 2.

Narayana, P. A. 2017. Kumpulan Artikel Mahasiswa Pendidikan Teknik Informatika (KARMAPATI): Film dokumenter tok lait kancing sebuah warisan karakter budaya bangsa, Volume 6 Nomor 1.

Riduwan. (2018). Cara mudah menyusun skripsi dan tugas akhir. Bandung: Alfabeta.

Sugiyono. (2017). Metode penelitian pendidikan (pendekatan kuantitatif, kualitatif, dan $R \& D)$. Bandung: CV. Alfabeta. 